\title{
ERRATUM
}

Open Access

\section{Erratum to: Metastatic Merkel cell carcinoma response to nivolumab}

Frances M. Walocko', Benjamin Y. Scheier², Paul W. Harms ${ }^{3,4}$, Leslie A. Fecher ${ }^{2}$ and Christopher D. Lao ${ }^{2 *}$

\section{Erratum}

Following publication of this article [1], it was noticed that the Clinical Trial Number in the last paragraph of the conclusions section was incorrectly listed as NCT02155647. The correct Clinical Trials Number is NCT02488759.

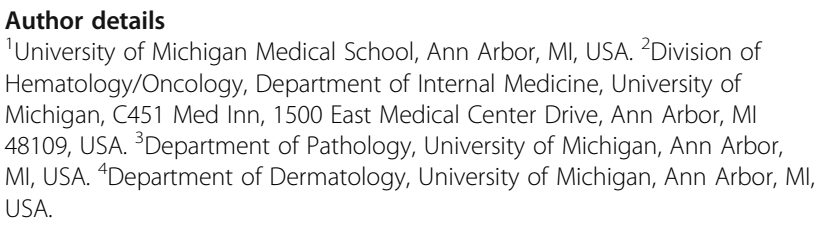

Received: 6 February 2017 Accepted: 7 February 2017

Published online: 06 March 2017

\section{Reference}

1. Walocko FM, Scheier BY, Harms PW, Fecher LA, Lao CD. Metastatic

Merkel cell carcinoma response to nivolumab. J Immunother Cancer

2016:4:79. doi:10.1186/s40425-016-0186-1.

\footnotetext{
* Correspondence: clao@med.umich.edu

2Division of Hematology/Oncology, Department of Internal Medicine,

University of Michigan, C451 Med Inn, 1500 East Medical Center Drive, Ann
}

Arbor, MI 48109, USA 